\title{
ANALISIS YURIDIS TERHADAP KEBIJAKAN DIVERSI PEMERINTAH DAERAH DALAM PERLINDUNGAN ANAK DI KABUPATEN KUNINGAN
}

\author{
Komar Hidayat, Yunusrul Zen dan Diding Rahmat \\ Fakultas Hukum Universitas Kuningan \\ Email : komarhidayat101994@gmail.com
}

\begin{abstract}
The writer does this research with background to know the rule of diversion policy specifically for children in Kuningan Regency. The purposes of writing this paper are to know how the rule and diversion system policy in child protection at this time and to analyze how juridical diversion policy in child protection in Kuningan Regency. The method that author used in this reseach is normative juridical approach by using secondary data collected through reading, understanding, quoting, summarazing, and making some notes and analyzing the legislation. The result of this research is that the rules and policies of the current diversion are governed by few rules the legislation including laws on the child criminal justice system, supreme court rules on the guidelines implementation of diversion in the criminal justice system the child who once analyzed it still has drawbacks. Juridical analysis of diversion policy on child protection in the Kuningan Regency. Kuningan local regulations related to diversi namely Kuningan Local Regulations about organization of child protection. The conlusion of this paper is that Kuningan local regulation is still common and does not adequately support the policies and the diversion or weaknesses are found in other regulations which should be complemented by Kuningan local regulations. The area of regulation is not equipped by the constitution of Indonesia Government for being complete.

Key words : Regulations, Diversion, Child.
\end{abstract}

\begin{abstract}
Abstrak
Penulis melakukan penelitian ini dengan latar belakang yaitu untuk mengetahui pengaturan kebijakan diversi terhadap anak khususnya di kabupaten kuningan. Tujuan penulisan ini untuk mengetahui bagaimana pengaturan dan kebijakan sistem diversi dalam perlindungan anak saat ini dan Untuk mengetahui bagaimana analisis yuridis kebijakan diversi dalam perlindungan anak di kabupaten kuningan. Metode yang digunakan dalam penelitian ini adalah dengan pendekatan yuridis normatif dengan menggunakan data sekunder dengan dengan cara pengumpulan data dengan membaca, memahami, mengutip, merangkum, dan membuat catatan-catatan serta menganalisis peraturan perundang-undangan. Hasil penelitian ini adalah pengaturan dan kebijakan diversi saat ini diatur oleh beberapa peraturan perundangan meliputi undang-undang tentang sistem peradilan pidana anak, peraturan mahkamah agung tentang pedoman pelaksanaan diversi dalam sistem peradilan pidana anak yang setelah dianalisis masih menyisakan kekurangan. Analisis yuridis kebijakan diversi dalam perlindungan anak di kabupaten kuningan adanya peraturan daerah kabupaten kuningan terkait dengan diversi yakni peraturan daerah kabupaten kuningan tentang penyelenggaraan perlidungan anak. Kesimpulan dari penulisan skripsi ini adalah setelah dianalisis peraturan daerah tersebut masih bersifat umum dan tidak secara memadai dan mendukung adanya kebijakan diversi dan kekurangan atau kelemahan yang ditemukan di peraturan lain diatasnya yang seharusnya dilengkapi oleh peraturan daerah tersebut, oleh peraturan daerah tersebut tidak dilengkapi padahal telah diamanatkan oleh undang-undang dasar negara kesatuan republik indonesia untuk dilengkapi.
\end{abstract}

Kata kunci : Pengaturan, Diversi, Anak. 


\section{PENDAHULUAN}

Anak merupakan sumber daya manusia yang berpotensi untuk meneruskan cita-cita bangsa Indonesia dimasa selanjutnya, anak memerlukan pembinaan dalam menjamin pertumbuhannya secara fisik, sosial, mental dengan cara bertahap dan seimbang. Sebagai sebuah pribadi yang sangat unik dan memiliki ciri yang khas, anak dapat bertindak berdasarkan perasaan, pikiran, dan kehendaknya sendiri, selain kehendaknya sendiri perbuatan atau perilaku anak juga dapat pula dipengaruhi dari lingkungan sekitarnya, seorang anak dapat melakukan tindakan atau perbuatan yang lepas kontrol, mereka dapat melakukan tindak pidana sehingga melanggar hukum, berdasarkan data yang dihimpun Pusat Data Anak Berhadapan Dengan Hukum (ABDH), sepanjang 2014 di Indonesia sedikitnya ada sekitar 2.879 anak melakukan tindak kekerasan dan harus berhadapan dengan hukum, mulai rentang usia 6-12 tahun sebanyak 268 anak $(9 \%)$, usia 13 tahun, modus paling banyak adalah kekerasan anak sebanyak 1.701 kasus, pencurian sebanyak 255 kasus, narkoba (pengguna) sebanyak 224 kasus, pelecehan seksual 198 kasus, pembunuhan 170 kasus, penggunaan senjata tajam 148 kasus, perkosaan 104 kasus, miras 47 kasus. Narkoba 25 kasus, dan lainnya 2 kasus, ${ }^{1}$ lebih lanjut menurut laporan Steven Allen lebih dari 4.000 anak Indonesia diajukan ke pengadilan setiap tahunnya atas kejahatan ringan seperti pencurian. Pada umumnya mereka tidak mendapat dukungan dari pengacara maupun dinas sosial. Maka dari itu sembilan dari sepuluh anak tersebut dijebloskan ke dalam penjara. ${ }^{2}$

1 Muttya Keteng, Andi. (2014, 30 Desember). Komnas PA Prediksi Pelaku Kekerasan Anak Meningkat 18\% Tahun 2015. Liputan 6 [Online], halaman 1. Tersedia: http://news.liputan6.com/read/2154228/komnas-paprediksi-pelaku-kekerasan-anak-meningkat-18-tahun-2015, 21 Februari 2017,, diakses tanggal 21 Februari 2017 pukul 10.45 .

2 Steven Allen, 2003, Analisa Situasi Peradilan Pidana Anak (Juvenile Justice Sistem) di Indonesia. UNICEF, Indonesia, hlm.1.
Pemidanaan/pemenjaraan itu lebih berorientasi kepada pertanggungjawaban individual/personal (Individual responsibility) dimana pelaku dipandang sebagai individu yang mampu untuk bertanggung jawab penuh terhadap perbuatan yang dilakukannya. Sedangkan anak merupakan individu yang belum dapat menyadari secara penuh atas tindakan/perbuatan yang dilakukannya, hal ini disebabkan karena anak merupakan individu yang belum matang dalam berpikir. Tanpa disadari hal tersebut tentu saja dapat menimbulkan dampak psikologis yang hebat bagi anak yang pada akhirnya mempengaruhi perkembangan mental dan jiwa dari si anak ${ }^{3}$ dan merampas hak yang mereka miliki.

Undang-Undang Dasar Negara Republik Indonesia 1945 telah menggariskan hak anak pada Pasal 28 B ayat (2) bahwa :" setiap anak berhak atas kelangsungan hidup, tumbuh dan berkembang serta berhak atas perlindungan dari kekerasan dan diskriminasi". Dicantumkannya hak anak dalam batang tubuh konstitusi dapat di artikan kedudukan perlindungan hak anak merupakan hal penting yang harus dijabarkan lebih lanjut dan di jalankan dalam kenyataan sehari-hari.

Undang-Undang Nomor 39 Tahun 1999 tentang Hak Asasi Manusia juga mengkhususkan hak anak didalam pasal 55 sampai 66, adapun hak anak dalam pasal-pasal tersebut pada intinya adalah anak memiliki hak-hak dasar yang harus mereka dapatkan mulai dari mereka dalam kandungan, lebih lagi bilamana anak melakukan tindakan yang melanggar hukum atau sering dikatakan berkonflik dengan hukum, anak memiliki hak yang tersendiri, anak tidak boleh dihukum seumur hidup, dan pemenjaraan terhadap anak adalah dijadikan upaya terakhir yang harus ditempuh.

Peraturan lainnya adalah Undang-Undang Nomor 11 Tahun 2012 tentang Sistem Peradilan

3 Novie Amalia Nugraheni, Sistem Pemidanaan Edukatif Terhadap Anak Sebagai Pelaku Tindak Pidana, Skripsi FH Undip, hlm 2. 
Pidana anak. Pembentukan Undang-Undang tersebut merupakan bentuk dari konkretisasi dari pelaksanaan konvesi Hak-hak anak yang telah diratifikasi oleh indonesia, Penjelasan umum Undang-undang Nomor 11 Tahun 2012 tentang Sistem Peradilan Pidana Anak menjelaskan bahwa Peratifikasian Konvensi Hak-Hak Anak agar Proses penjatuhan pidana kepada anak yang berkonflik dengan hukum dianggap bukanlah solusi terbaik dalam menyelesaikan tindak pidana yang dilakukan oleh anak.

Perlindungan kepentingan anak yang berkonflik dengan hukum dapat ditempuh dengan pendekatan restorative juctice, yang dilaksanakan dengan cara pengalihkan (diversi). Konsep diversi didasarkan pada kenyataan bahwa proses peradilan pidana terhadap anak pelaku tindak pidana melalui sistem peradilan pidana lebih banyak menimbulkan bahaya daripada kebaikan, sehingga lebih baik untuk menghindarkannya ke luar sistem peradilan pidana.

Guna menciptakan Kabupaten yang ramah anak dan mewujudkan Kuningan sebagai Kabupaten ramah Anak, Kuningan sendiri sudah mempunyai Peraturan Daerah Kabupaten Kuningan yang dikeluarkan yakni Peraturan Daerah Nomor 15 Tahun 2013 tentang Penyelenggaraan Perlindungan Anak.

\section{RUMUSAN MASALAH}

Berdasar latar belakang masalah diatas, tedapat beberapa permasalahan yang dapat dirumuskan sebagai berikut : Bagaimana pengaturan dan kebijakan sistem Diversi dalam perlindungan anak saat ini? Dan Bagaimana Analisis yuridis kebijakan Diversi dalam Perlindungan Anak di Kabupaten Kuningan?

\section{METODE PENELITIAN}

Penelitian ini menggunakan pendekatan yuridis-normatif, yaitu dengan mengkaji atau menganalisis data sekunder dengan memahami hukum sebagai perangkat peraturan atau norma-norma positif di dalam sistem perundang-undangan yang mengatur mengenai permasalahan dalam penelitian ini. Jadi penelitian ini dipahami sebagai penelitian kepustakaan, yaitu penelitian terhadap data sekunder. ${ }^{4}$ Teknik pengumpulan data yang akan digunakan sebagai sumber di dalam penelitian ini adalah studi kepustakaan dan studi dokumentasi. Bahan hukum primer dalam penelitian ini yaitu Undang-Undang Dasar Negara Republik Indonesia 1945, UndangUndang Nomor 11 Tahun 2012 tentang Sistem Peradilan Pidana Anak, dan Peraturan Daerah Nomor 15 Tahun 2013 tentang Penyelenggaraan Perlindungan Anak.

\section{PEMBAHASAN}

\section{Pengaturan Dan Kebijakan Sistem Diversi Dalam Perlindungan.}

Indonesia memiliki Undang-Undang Nomor 11 Tahun 2012 tentang Sistem Peradilan Pidana Anak, undang-undang tersebut adalah hasil dari ratifikasi Konvensi dan Konvenan yang berkaitan dengan Hak-Hak Anak dan Perlindungan Anak. Dokomen Konvensi dan Konvenan Perserikatan Bangsa-Bangsa (PBB) yang telah diratifikasi itu dijadikan rujukan/pedoman dalam hal pembuatan Peraturan perundang-undangan, Indonesia sebagai Negara Anggota PBB wajib mengeluarkan peraturan yang berpedoman pada dokumen tersebut.

Isi dokumen Rujukan/pedoman yang dijadikan salah satu isi dari Undang-Undang Nomor 11 Tahun 2012 adalah mengenai Kebijakan Diversi, Diversi Menurut Pasal 1 ayat (7) adalah pengalihan penyelesaian perkara Anak dari proses peradilan pidana ke proses di luar peradilan pidana.

Tujuan dari proses diversi adalah mencapai Perdamaian antara korban dan anak, menyelesaikan perkara anak diluar proses peradilan, menghindarkan anak dari perampasan kemerdekaan, mendorong masyarakat untuk berpartispasi dan menanamkan rasa tanggung jawab kepada anak. Tujuan diversi ini berguna bagi anak sebagai pelaku tindak pidana agar tidak terganggu pertumbuhan psikologis anak,

${ }^{4}$ Soerjono Soekanto \& Sri Mamudji, 1985 Penelitian Hukum Normatif, Suatu Tinjauan Singkat, Jakarta: Rajawali, hlm. 15. 
karena kebijakan diversi dalam peraturan ini berusaha agar pemenjaraan terhadap anak adalah sebagai upaya terakhir, karena pemenjaraan bagi anak adalah sebuah kekerasan, dapat di pahami bahwa kekerasan pada anak adalah tindakan kekerasan secara fisik, psikologis, dan sosial.

Kebijakan diversi pada Undang-Undang Nomor 11 Tahun 2012 ini hanya dapat dilakukan jika anak sebagai pelaku tindak pidana diancam dengan hukuman dibawah 7(tujuh) tahun dan bukan pengulangan terhadap tindak pidana, persyaratan ini bertujuan agar anak tidak akan melanggar hukum secara berulang-ulang dan upaya diversi ini sebagai upaya penyadar bagi anak yang melakukan tindak pidana.

Pengaturan terhadap Kebijkan Diversi dalam Undang-Undang Nomor 11 Tahun 2012 dinilai masih mengatur hal-hal pokok tentang diversi maka Mahkamah Agung mengeluarkan Peraturan Mahkamah Agung/PERMA Nomor 4 Tahun 2014 untuk melengkapi hal-hal yang belum diatur dalam Undang-Undang Nomor 11 Tahun 2012 berkenaan dengan diversi.

Pengaturan lain Kebijakan Diversi dalam Peraturan Mahkamah Agung/PERMA diantaranya adalah bahwa kewajiban diversi dilakukan bagi anak yang telah berumur 12 (dua belas) tahun tetapi belum berumur 18 (delapan belas) tahun atau telah berumur 12 (dua belas) tahun mesikpun pernah kawin tetapi belum berumur 18 (delapan belas tahun), yang diduga melakukan tindak Pidana.

Pengaturan lainnya mengenai kebijakan diversi dalam Peraturan Mahkamah Agung/PERMA adalah mengenai kesepakatan diversi yang didalamnya mengatur bahwa antara kedua belah pihak melakukan kesepakatan hitam diatas putih yang di jadikan Berita Acara oleh fasilitator dan penitera dari pengadilan, dan kemudian Ketua Pengadilan mengeluarkan Penetapan Kesepakatan Diversi berdasarkan Kesepakatan Diversi tersebut. Kemudian dalam menjatuhkan Putusan Hakim wajib mempertimbangkan hasil kesepakatan diversi yang telah menjadi Berita Acara tersebut.

Adanya Undang-Undang Nomor 1 Tahun 2016 tentang perlindungan anak, Undang-
Undang Nomor 11 Tahun 2012 tentang Sistem Peradilan Pidana Anak serta Peraturan Mahkamah Agung Nomor 4 Tahun 2014 yang di dalamnya mengatur mengenai kebijakan diversi, ini menandakan bahwa perlindungan terhadap anak dengan upaya diversi yang dimuat dalam peraturan-peraturan tersebut telah diakui, dan adanya peraturan hukum yang berlaku tersebut menegaskan bahwa Indonesia adalah Negara Hukum, ini menandakan dengan pasti bahwa Indonesia adalah Negara Hukum, seperti halnya yang telah tercantum Pada Pasal 1 ayat (3) mengatakan Bahwa "Indonesia adalah Negara Hukum" seperti halnya pendapat Ann Van Wynen Thomas, Negara hukum dikelompokan menjadi 3 kategori sebagai berikut :

a. Pandangan yang memandang hukum tidak lain dari pengaturan dari pihak otoritas untuk menyelesaikan hubungan-hubungan hukum, yang dilaksanakan sesuai dengan kehendak dan kekuasaan dari penguasa. Karena itu, konsep rule of law dalam pengertian ini berarti keharusan adanya suatu ketertiban umum yang dipertahankan bila perlu melalui upaya paksa atau ancaman-ancaman. Sehingga, konsep rule of law dalam pengertian ini tidak memiliki misi untuk membatasi kegiatan, kukuasaan, dan kedaulatan negara.

b. Pandangan yang memandang rule of law tidak hanya merupakan pengaturan pihak otoritas untuk menyelesaikan hubunganhubungan hukum, melainkan juga menerima pengaturan dan pembatasan terhadap tugas-tugas otoritas.

c. Pandangan yang memandang rule of law sebagai konsensus dari masyarakat untuk suatu ketertiban, sesuai prinsip-prinsip moral dan keadilan. ${ }^{5}$

Pasal yang bisa dikatakan masuk kedalam kategori dapat kita lihat dalam Undang-Undang Nomor 11 Tahun 2012 tentang Sistem Peradilan Pidana anak pada Pasal 9 ayat (1) yang menyebutkan bahwa Penyidik, Penuntut Umum, dan Hakim dalam melakukan Diversi harus

${ }^{5}$ Munir Fuady, 2011, Teori Negara Hukum Modern (rechtstaat), Bandung: Refika Aditama, hlm. 5. 
mempertimbangkan kategori tindak pidana, umur Anak hasil penelitian kemasyarakatan dari $B$, dan dukungan lingkungan keluarga dan masyarakat. Pasal ini menjelaskan bahwa rule of law tidak hanya memandang pihak otoritas untuk menyelesaikan hubungan-hubungan hukum, melainkan juga menerima pengaturan dan pembatasan terhadap tugas-tugas otoritas.

Dengan telah hadirnya peraturan Perundang-undangan dan peraturan dibawahnya yang mengatur Diversi, kita tidak bisa pisahkan dengan Teori Legislasi, ini diawali dengan adanya suatu pemikiran yang berkaitan dengan perencanaan peraturan perundang-undangan yang di agendakan, Teori Legislasi memiliki bererapa Prinsip diantaranya adalah :

a. Prinsip Manfaat, Manfaat adalah suatu istilah abstrak, istilah ini mengungkapkan sifat dasar atau kecenderungan sesuatu untuk mencegah kejahatan atau memperoleh kebaikan. Kejahatan adalah penderitaan atau penyebab penderitaan, kebaikan adalah kesenangan atau penyebab kesenangan. Yang paling sesuai dengan manfaat atau kepentigan seorang individu adalah yang cenderung memperbanyak jumlah kebahagiaan itu. Yang paling sesuai dengan manfaat atau kepentingan masyarakat adalah yang cenderung memperbesar jumlah kebahagian individu yang membentuk masyarakat itu.

b. Prinsip Asketik, Prinsip ini berlawanan dengan prinsip manfaat, prinsip ini menyetujui segala hal yang cenderung membatasi kesenangan dan menyalahkan segala hal yang cenderung menambah kesenangan.

c. Prinsip Yang Sewenang-wenang atau prinsip simpati dan antipati, Prinsip ini ada karena sikap menyetujui atau menyalahkan berdasarkan perasaan tanpa memberikan alasan lain bagi keputusan itu, kecuali keputusan itu sendiri. Saya senang, saya tidak senang: keduannya menjadi poros perputaran prinsip ini. Suatu tindakan dinilai baik atau buruk bukan karena tindakan itu sesuai atau bertentangan dengan kepentingan mereka yang dipengaruhinya, namun karena tindakan itu tindakan itu menyenangkan atau menjengkelkan bagi orang yang menilai. "inilah desakan dari dalam diri saya; ini adalah keyakinan saya yang terbesar; saya merasakannya." Seperti itulah nada despotik yang keluar dari keputusan-keputusan tersebut. ${ }^{6}$

Melihat beberapa prinsip yang ada dalam Teori Legislasi, pembuat undang-undang atau Legislator yang mengatur mengenai diversi, cenderung menggunakan prinsip manfaat dan prinsip yang sewenang-wenang atau prinsip simpati dan antipati, karena dalam setiap pasal yang berhubungan dengan diversi dalam peraturan perundang-undangan dan aturan lain dibawahnya bermaksud memberikan kebaikan kepada anak yang menjadi pelaku atau korban dengan adanya sistem diversi tersebut, manfaat atau kabaikan itu tercermin dalam pasal yang mengatakan bahwa penghukuman terhadap anak, atau pemenjaraan kepada anak adalah sebagai jalan terakhir, pasal ini diharapkan memberikan dampak atau manfaat kebaikan untuk perkembangan psikologis anak baik yang berkonflik dengan hukum atau anak sebagai korban dari pelanggaran hukum.

Prinsip kesewenang-wenangan atau prinsip simpati atau antipati, prinsip ini lebih cenderung menitik beratkan kepada pendapat pribadi pembuat peraturan perundang-undangan dan peraturan lain dibawahnya yang berkaitan dengan diversi, prinsip ini menghasilkan peraturan perundang-undangan dan aturan lain dibawahnya akibat hasil dari dorongan dalam diri pembuat peraturan, ini bukan perasaan moral, melainkan akal sehatlah yang mengatakan apa yang baik adan apa yang buruk, akal sehat adalah suatu pemahaman yang dimiliki semua orang. Dari sanalah aturan perundang-undangan dan aturan lain dibawahnya di buat.

Hasil prinsip ini tercermin pada Pasal 5 ayat (6) dan (9) Peraturan Mahkamah Agung/PERMA Nomor 4 Tahun 2014 yang berbunyi bila dipandang perlu fasilitator

6 Jeremy Bentham, 2016, Teori PerundangUndangan, Prinsip-prinsip Legislasi, Hukum Perdata dan hukum Pidana, Bandung: Penerbit Nuansa, hlm. 25. 
Diversi dapat memanggil masayarakat maupun pihak lain untuk memberikan informasi untuk mendukung penyelesaian; Dalam menyususn kesepakatan diversi, Fasilitator Diversi memperhatikan dan mengarahkan agar kesepakatan tidak bertentangan dengan hukum, agama, kepatutan masyarakat setempat, kesusilaan; atau memuat hal-hal yang tidak dapat dilaksanakan Anak, atau memuat itikad tidak baik.

Semua tujuan diversi yang ingin dicapai oleh legislator oleh prinsip diatas kelihatan baik, harus kita dukung kepada prinsip itu tanpa ada kebaikan umum untuk suatu tujuan tunggal dan independen, misalnya moral yang baik, kesetaraan, kebebasan, keadilan, agama dan sebagainya, semua tujuan yang patut dihormati, tujuan yang bagus harus masuk pada pandangan legislator, kecuali tujuan yang sudah sering menyesatkan. ${ }^{7}$

Sebagai Legislator jangan sampai cenderung membuat peraturan atau undangundang yang menjadi tugas dan agendanya hanya terpaku kepada prinsip-prinsip dalam pembuatan undang-undang, karena pembatasan ini akan mengakibatkan pembatasan pula pada produck hukum yang dihasilkan, apalagi kepada tujuan pembuatan peraturan atau undangundang tersebut, legislator harus bisa melihat apakah undang-undang atau aturan mengenai diversi tersebut bisa menjadi sarana kebahagiaan anak atau tidak, dapat berjalan atau tidak, bermanfaat atau tidak, dan sebagainya.

Berbicara mengenai apakah undangundang mengenai diversi diatas bisa menjadi sarana kebahagiaan anak atau tidak, hal ini tidak akan lepas dari Teori Keadilan, keadilan menurut John Rawls adalah kebijakan utama dalam institusi sosial, sebagaimana kebenaran dalam sistem pemikiran, suatu teori betapapun elegan dan ekonomisnya, harus di tolak atau direvisi jika ia tidak benar demikian juga hukum dan institusi, tidak peduli betapapun efisien dan rapinya, harus di reformasi atau dihapuskan jika tidak adil. Setiap orang memilki kehormatan

${ }^{7}$ Ibid, hlm. 38. yang berdasar pada keadilan sehingga seluruh masyarakat sekalipun tidak bisa membatalkannya.

Atas dasar ini keadilan menolak jika lenyapnya kebebasan bagi sejumlah orang dapat dibenarkan oleh hal lebih besar yang didapatkan orang lain. Keadilan tidak membiarkan pengorbanan yang dipaksakan pada segilintir orang diperberat oleh sebagian besar keuntungan yang dinikmati banyak orang, karena itu di dalam masyarakat yang adil kebebasan warga negara dianggap mapan, hak-hak yang dijamin oleh keadilan tidak tunduk pada tawar menawar politik atau kalkulasi kepentingan sosial. $^{8}$

Ada beberapa prinsip dari teori keadilan menurut john Rawls yakni Prinsip pertama tersebut dikenal dengan "prinsip kebebasan yang sama" (equal liberty principle), seperti misalnya kemerdekaan berpolitik (political of liberty), kebebasan berpendapat dan mengemukakan ekspresi (freedom of speech and expression), serta kebebasan beragama (freedom of religion).

Sedangkan prinsip kedua bagian (a) disebut dengan "prinsip perbedaan" (difference principle) dan pada bagian (b) dinamakan dengan "prinsip persamaan kesempatan" (equal opportunity principle). "Prinsip perbedaan" pada bagian (a) berangkat dari prinsip ketidaksamaan yang dapat dibenarkan melalui kebijaksanaan terkontrol sepanjang menguntungkan kelompok masyarakat yang lemah. Sementara itu prinsip persamaan kesempatan yang terkandung pada bagian (b) tidak hanya memerlukan adanya prinsip kualitas kemampuan semata, namun juga adanya dasar kemauan dan kebutuhan dari kualitas tersebut. Sehingga dengan kata lain, ketidaksamaan kesempatan akibat adanya perbedaan kualitas kemampuan, kemauan, dan kebutuhan dapat dipandang sebagai suatu nilai yang adil berdasarkan persepktif Rawls. ${ }^{9}$

Prinsip persamaan kesempatan menurut Rawls yang mengatakan bahwa yang dikatakan

\footnotetext{
${ }^{8}$ John Rawls, 1971, A theori, hlm. 3.

9 Pan Mohamad Fais, 2009, "Teori Keadilan Jhon Rawls", University of Queensland, Jurnal Konstitusi, hlm. 141.
} 
adil itu harus di sesuaikan dengan kualitas dan kemampuan, kemauan, dan kebutuhan, ini tercermin dalam pengaturan mengenai diversi di Undang-Undang dan Peraturan lain pendukungnya, kita ketahui bahwa anak berbeda dengan orang dewasa maka dalam hal jika anak melakukan tindak pidana maka dalam proses hukumnya anak harus berbeda dengan orang dewasa ini berdasar atas kemampuan dan kebutuhan anak untuk menjauhkan anak yang berkoflik dengan hukum dari hal-hal yang dapat mengganggu pertumbuhannya dan kekerasan yang dapat diterima oleh anak yang berkonflik dengan hukum.

Prinsip ini termuat dalam Pasal 3 UndangUndang Nomor 11 Tahun 2012 yang menyatakan bahwa setiap Anak dalam proses peradilan pidana berhak diperlakukan secara manusiawi dengan memperhatikan kebutuhan sesuai dengan umurnya, dipisahkan dari orang dewasa, memperoleh bantuan hukum dan bantuan lain secara efektif, melakukan kegiatan rekreasional, bebas dari penyiksaan, penghukuman atau perlakuan lain yang kejam, tidak manusiawi, serta merendahkan derajat dan martabatnya, tidak dijatuhi pidana mati atau pidana seumur hidup, tidak ditangkap, ditahan, atau dipenjara, kecuali sebagai upaya terakhir dan dalam waktu yang paling singkat, memperoleh keadilan di muka pengadilan Anak yang objektif, tidak memihak, dan dalam sidang yang tertutup untuk umum, tidak dipublikasikan identitasnya, memperoleh pendampingan orang tua/Wali dan orang yang dipercaya oleh Anak, memperoleh advokasi sosial, memperoleh kehidupan pribadi, memperoleh aksesibilitas, terutama bagi anak cacat, memperoleh pendidikan, memperoleh pelayananan kesehatan, dan memperoleh hak lain sesuai dengan ketentuan peraturan perundang-undangan.

Kemudian Prinsip persamaan kesempatan dengan Pasal yang berkaitan dengan Diversi termuat pula dalam Pasal 10 ayat (2) UndangUndang Nomor 11 Tahun 2012 yang menyatakan bahwa Kesepakatan Diversi sebagaimana dimaksud pada ayat (1) dilakukan oleh Penyidik atas rekomendasi Pembimbing Kemasyarakatan dapat berbentuk pengembalian kerugian dalam hal ada korban, rehabilitasi medis dan psikososial, penyerahan kembali kepada orang tua/Wali, keikutsertaan dalam pendidikan atau pelatihan di lembaga pendidikan atau LPKS paling lama 3 (tiga) bulan; atau pelayanan masyarakat paling lama 3 (tiga) bulan.

Dalam Peraturan Mahkamah Agung/PERMA Nomor 4 Tahun 2014 Pasal 2 menyatakan bahwa Diversi diberlakukan terhadap anak yang telah berumur 12 (dua belas) tahun tetapi belum berumur 18 (delapan belas) tahun atau telah berumur 12 (dua belas) tahun meskipun pernah kawin tetapi belum berumur 18 (delapan belas) tahun, yang diduga melakukan tindak pidana.

Pengaturan batasan usia pemberlakuan diversi dalam Peraturan Mahkamah Agung/PERMA diatas menjelaskan bahwa usia anak yang telah disebutkan, dianggap belum mampu untuk bisa bertanggung jawab untuk menjalani pemenjaraan atau hukuman, jika kita cocokan dengan prinsip persamaan kesempatan dari teori keadilan, bahwa keadilan itu harus disesuaikan diantaranya yakni dengan kemampuan, maka di usia tersebut seorang anak masih dianggap belum mampu, sehingga kebijakan diversi lah yang harus wajib digunakan.

Melihat hal itu dapat memunculkan pertanyaan, bagaimana dengan anak yang melakukan tindak pidana tetapi belum berumur 12 tahun, dengan melihat pengaturan batasan umur tersebut, maka anak yang melakukan tindak pidana sebelum umur 12 tahun tersebut tidak mendapatkan kesempatan untuk menggunakan kebijakan diversi, munculah ketidakadilan bagi anak tersebut. Ini salah satu kelemahan dari Undang-Undang Nomor 11 Thun 2012 dan Peraturan Mahkamah Agung/PERMA Nomor 4 Tahun 2014 karena tidak mengatur hal ini, walaupun akhirnya akan dikembalikan ke orang tua/wali, tetapi akan muncul lagi ketidakadilan bagi korban dari perbuatan pelanggaran tindak pidana yang dilakukan oleh anak yang masih dibawah 12 (dua belas) tahun tersebut.

Bukan halnya itu dengan adanya batasan umur yang telah disebutkan diatas dalam hal 
syarat untuk menerapkan kebijakan diversi, pengaturan batasan umur tersebut memunculkan lagi kelemahan dalam UndangUndang Nomor 11 Tahun 2012 dan Perturan Mahkamah Agung/PERMA Nomor 4 Tahun 2014 sebagai pelengkapnya dalam hal pengaturan kebijakan Diversi, permasalahan yang muncul yakni manakala anak yang belum berusia 18 Tahun kemudian melakukan tindak pidana, kemudian korban dan anak yang berkonflik dengan hukum tersebut melakukan diversi, sehingga kesepakatannya di sahkan dan di jadikan Berita Acara dan sebagai pedoman Hakim untuk memutus perkara tersebut, tidak disangka setelah si anak berumur lebih dari 18 tahun, anak pelaku tindak pidana tersebut melakukan tindakan pidana kepada korban dan tindakan yang sama pula seperti tindak pidana sebelum melakukan diversi. Bagaimana cara penyelesaian pelanggaran dari kesepakatan diversi yang dilakukan anak pelaku tindak Pidana tersebut, secara bahwa Undang-Undang Nomor 11 Tahun 2012 dan Peraturan Mahkamah Agung/PERMA Nomor 4 Tahun 2014 tidak mampu menyelesaikan pelanggaran terhadap kesepakatan diversi tersebut karena tidak diatur dalam kedua peraturan tersebut.

Kepentingan anak dalam proses diversi yang dinilai masih ada yang belum diatur dalam Undang-Undang Nomor 11 Tahun 2012 dan Peraturan Mahkamah Agung/PERMA Nomor 4 Tahun 2014, kemudian permasalahan diatas menjadi suatu kelemahan, maka menurut Teori Perlindungan Hukum yang menyatakan bahwa hukum merupakan jaminan bagi kegiatan perlindungan anak. Maka karena masih adanya kelemahan yang telah disebutkan diatas dalam perlindungana anak dengan kebijakan diversi yang masih belum di atur seutuhnya dalam peraturan perundang-undangan dan peraturan lain dibawahnya, maka perlindungan hukum terhadap anak masih belum dikatakan terwujud walaupun sudah ada Undang-Undang Nomor 11 Tahun 2012 dan Peraturan Mahkamah Agung/PERMA Nomor 4 Tahun 2014, ini karena masih ada hak-hak anak yang masih belum secara rinci terlindungi, menurut Teori HakHak Anak (Konvensi Hak-Hak Anak) menyatakan dalam Prinsip-prinsipnya bahwa anak memiliki hak:

a. Prinsip non-diskriminasi, Artinya semua hak yang diakui dan terkandung dalam Konvensi Hak Anak harus diberlakukan kepada setiap anak tanpa pembedaan apapun. Prinsip ini tertuang dalam Pasal 2 ayat (1) Konvensi Hak Anak, yakni :"Negara-negara peserta akan menghormati dan menjamin hak-hak yang diterapkan dalam konvensi ini bagi setiap anak yang berada dalam wilayah hukum mereka tanpa diskriminasi dalam bentukapapun, tanpa memandang ras, warna kulit, jenis kelamin, bahasa, agama, pandangan politik atau pandangan-pandangan lain, asal-usul kebangsaan, etnik atau sosial, status kepemilikan, cacat atau tidak, kelahiran atau status lainnya baik dari si anak sendiri atau dari orang tua atau walinya yang sah". Pasal 2 ayat (2) berisi ketentuan bahwa, Negara-negara peserta akan mengambil semua langkah yang perlu untuk menjamin agar anak dilindungi dari semua bentuk diskriminasi atau hukuman yang didasarkan pada status, kegiatan, pendapat yang dikemukakan atau keyakinan dari orang tuamanak, walinya yang sah atau anggota keluarga". (Ayat 2).

b. Prinsip yang terbaik bagi anak (best interest of the child). Pasal 3 ayat (1) berisi ketentuan bahwa, Dalam semua tindakan yang menyangkut anak yang dilakukan oleh lembaga-lembaga kesejahteraan sosial pemerintah atau badan legislatif, kepentingan yang terbaik bagi anak harus menjadi pertimbangan utama (Pasal 3 ayat (1)).

c. Prinsip atas hak hidup, kelangsungan dan perkembangan (the rights to life, survival and development). Pasal 6 ayat (1) berisi ketentuan bahwa, Negara-negara peserta mengakui bahwa setiap anak memiliki hak yang melekat atas kehidupan. Pasal 6 ayat (2) berisi ketentuan bahwa, negara-negara peserta akan menjamin sampai batas maksimal kelangsungan hidup dan perkembangan anak. 
d. Prinsip penghargaan terhadap pendapat anak (respect for the views of the child), Pendapat anak, terutama jika menyangkut hal-hal yang mempengaruhi kehidupannya, perlu diperhatikan dalam setiap pengambilan keputusan. Prinsip ini tertang dalam Pasal 12 ayat (1)

e. Konvensi Hak Anak, yaitu : Negara-negara peserta akan menjamin agar anak-anak yang mempunyai pandangan sendiri akan memperoleh hak untuk menyatakan pandangan-pandangannya secara bebas dalam semua hal yang mempengaruhi anak, dan pandangan tersebut akan dihargai sesuai dengan tingkat usia dan kematangan anak.

Kelemahan yang ditemukan dalam pengaturan kebijakan Diversi dalam UndangUndang Nomor 11 Tahun 2012 dan Peraturan Mahkamah Agung/PERMA Nomor 4 Tahun 2014, kelemahan ini melanggar prinsip dari Teori HakHak Anak Prinsip itu yakni Non-Diskriminasi, Prinsip yang terbaik bagi anak, dan Prinsip atas hak hidup, kelangsungan dan perkembangan. Sehingga dengan telah adanya pula UndangUndang Nomor 11 Tahun 2012 dan Peraturan Mahkamah Agung/PERMA Nomor 4 Tahun 2014 hak-hak yang seharusnya di terima oleh anak berkenaan dengan diversi, menjadi tidak diterima oleh anak karena belum diatur secara lengkap di Undang-Undang yang bertujuan untuk melindungi hak anak tersebut.

Analisis Yuridis Kebijakan Diversi dalam Perlindungan Anak Di Kabupaten Kuningan.

Peraturan Daerah merupakan salah satu sarana transformasi sosial dan demokrasi sebagai perwujudan kemampuan masyarakat daerah untuk menjawab perubahan yang cepat dan tantangan pada era otonomi saat ini, serta sebagai sarana mewujudkan good local governance sebagai bagian dari pembangunan yang berkesinambungan di daerahnya masingmasing dan sebagai pendukung berjalannya peraturan perundang-undangan di atasnya.

Pembentukan Peraturan Daerah yang terencana akan menghasilkan peraturan yang baik bagi semua sektor, termasuk terkhusus bagi anak yang berkonflik dengan hukum, ini agar semua hak-hak yang dimiliki seorang anak akan dapat terlindungi.

Kabupaten Kuningan memiliki Peraturan Daerah yang tujuan pembuatannya yakni untuk melindungi anak yang tercantum pada Peraturan Daerah Nomor 15 Tahun 2013 Tentang Penyelenggaraan Perlindungan Anak, disayangkan hanya 2 (dua) Pasal yang isinya bertujuan agar anak dijauhkan dari pemejaraan atau mendukung upaya diversi. Yakni dalam Pasal 16 yang menyebutkan :

a. Setiap anak berhak memperoleh perlindungan dari sasaran penganiayaan, penyiksaan, atau penjatuhan hukuman yang tidak manusiawi;

b. Setiap anak berhak untuk memperoleh kebebasan sesuai dengan hukum;

c. Penangkapan, penahanan, atau tindak pidana penjara anak hanya dilakukan apabila sesuai dengan hukum yang berlaku dan hanya dapat dilakukan sebagai upaya terakhir.

Dan Pasal 17 menyebutkan : Setiap anak yang dirampas kebebasannya berhak untuk:

a. Mendapatkan perlakuan secara manusiawi dan penempatannya dipisahkan dari orang dewasa;

b. Memperoleh bantuan hukum atau bantuan lainnya secara efektif dalam setiap tahapan upaya hukum yang berlaku; dan

c. Membela diri dan memperoleh keadilan di depan pengadilan anak yang objektif dan tidak memihak dalam sidang tertutup untuk umum.

d. Setiap anak yang menjadi korban atau pelaku kekerasan seksual atau yang berhadapan dengan hukum berhak dirahasiakan

Perlu dipahami bahwa Peraturan Daerah mempunyai kedudukan yang strategis, karena diberikan landasan konstitusional yang jelas sebagaimana diatur dalam Pasal 18 ayat (6) Undang-undang Dasar Republik Indonesia Tahun 1945. Peraturan Daerah memiliki beberapa fungsi, seperti sebagai instrumen kebijakan untuk melaksanakan otonomi daerah dan tugas pembantuan sebagaimana amanat UndangUndang Dasar Negara Republik Indonesia Tahun 
1945 dan Undang-Undang tentang Pemerintahan Daerah. Kemudian, fungsi yang kedua sebagai penampung kekhususan dan keragaman daerah, serta penyalur aspirasi masyarakat di daerah. Namun, pengaturannya tetap dalam kerangka Negara Kesatuan Republik Indonesia yangg berlandaskan Pancasila dan Undang-Undang Dasar Negara Republik Indonesia Tahun 1945. Yang ketiga, berfungsi sebagai alat pembangunan dalam meningkatkan kesejahteraan daerah.

Fungsi Peraturan Daerah seperti yang telah disebutkan di atas salah satunya adalah sebagai tugas pembantuan sebagaimana amanat Undang-Undang Dasar Negara Republik Indonesia Tahun 1945 dan Undang-Undang tentang Pemerintahan Daerah, tugas Pembantuan sebagai fungsi dari Peraturan Daerah bermaksudkan agar segala yang belum diatur secara lengkap dan menjadi titik lemah dalam Undang-Undang yang berkaitan atau berhubungan dengan Peraturan Daerah tersebut, bisa dilengkapi oleh Peraturan Daerah atau aturan lain dibawahnya, khususnya mengenai kebijakan diversi.

Undang-Undang Nomor 11 Tahun 2012 dan Peraturan Mahkamah Agung/PERMA Nomor 4 Tahun 2014 yang masih menyisakan kelemahan mengenai diversi atau kekurangan yang belum diatur dalam Undang-Undang dan Peraturan Mahkamah Agung/PERMA diatas yang seharusnya di atur dalam Peraturan Daerah, tetapi dalam Peraturan Daerah Kuningan sama sekali tidak menyinggung hal ini atau melengkapi kelemahan yang di temukan dalam undangundang dan peraturan lain diatasnya yang mengatur khususnya mengenai Diversi.

Jika kita kaitkan dengan Teori Legislasi, teori ini mempunyai tujuan yakni untuk menciptakan modifikasi dalam kehidupan masyarakat. Artinya isi dari peraturan harus berasal dari segala kehidupan masyarakat yang kemudian dijadikan peraturan oleh legislator, seperti halnya dengan Peraturan Daerah Kuningan seharusnya berisi muatan kehidupan masyarakat Kuningan yang dijadikan isi dari Peraturan Daerah tersebut, tetapi dari hasil penelitian Penulis dari isi Peraturan Daerah
Kuningan Nomor 15 tahun 2013 tidak ada satu pasal pun yang menyatakan ke khususan kehidupan masyarakat Kuningan yang dijadikan sebagai isi dari Peraturan Daerah Kuningan tersebut apalagi dengan pengaturan tentang penerapan diversi. Sama sekali tidak ada.

Peraturan Daerah Kuningan lebih bersifat Umum tidak melengkapi aturan yang kurang/lemah yang belum di atur oleh aturan lain diatasnya lebih khusus mengenai Diversi, dan Peraturan Daerah ini tidak menggambarkan muatan kehidupan masyarakat Kuningan. Contoh salah satu Pasal dalam Peraturan Daerah Kuningan Nomor 15 Tahun 2013 yang menurut penulis masih bersifat umum salah satunya yakni Pasal 8 yang menyatakan setiap anak berhak memperoleh pelayanan kesehatan dan jaminan sosial sesuai dengan kebutuhan fisik, mental, spirituall, dan sosial. Penerapan diversi wajib diupayakan untuk menyelesaikan tindak pidana yang pelakunya adalah anak. ${ }^{10}$

\section{SIMPULAN}

Berdasarkan uraian diatas maka penulis membuat simpulan yang dapat ditarik dari pemaparan tulisan diatas yaitu : Bahwa Pengaturan Kebijakan Diversi terdapat dalam Undang-Undang Nomor 11 Tahun 2012 tentang Sistem Peradilan Pidana Anak, dan Peraturan Mahkamah Agung/PERMA Nomor 4 Tahun 2014 mengenai Pedoman Pelaksanaan Diversi Dalam Sistem Peradilan Pidana Anak, Peraturan Mahkamah Agung/PERMA Ini sebagai pelengkap dari Undang-Undang Nomor 11 Tahun 2012. Setelah dianalisis bahwa peraturan-peraturan tersebut masih menyisakan kelemahan yang harus segera diatasi oleh peraturan lain dibawahnya yakni Peraturan daerah Kabupaten. Sebagaimana telah diatur dalam Pasal 18 ayat (6) Undang-undang Dasar Republik Indonesia Tahun 1945. Peraturan Daerah memiliki fungsi, seperti sebagai instrumen kebijakan untuk melaksanakan otonomi daerah dan tugas

\footnotetext{
${ }^{10}$ Sekhroni, Criminal Liability dan Diversi Terhadap Tindak Pidana Anak dalam Sistem Peradilan Anak di Indonesia, Jurnal Unifikasi, ISSN 2354-5976 Vol. 03 Nomor 01 Januari 2016,Kuningan: FH UNIKU. HIm. 36-64. DOI: https://doi.org/10.25134/unifikasi.v3i1.405
} 
pembantuan sebagaimana amanat UndangUndang Dasar Negara Republik Indonesia Tahun 1945 dan Undang-Undang tentang Pemerintahan Daerah dan Kabupaten Kuningan memiliki Peraturan Daerah yang tujuan pembuatannya yakni untuk melindungi anak, peraturannya tercantum pada Peraturan Daerah Nomor 15 Tahun 2013 Tentang Penyelenggaraan Perlindungan Anak, di Peraturan Daerah Kuningan tersebut tidak secara spesifik mengatur mengenai diversi dan terkesan umum berkenaan dengan Perlindungan anak, namun peneliti menemukan 2 (dua) Pasal yakni dalam Pasal 16 yang menyebutkan :

a. Setiap anak berhak memperoleh perlindungan dari sasaran penganiayaan, penyiksaan, atau penjatuhan hukuman yang tidak manusiawi;

b. Setiap anak berhak untuk memperoleh kebebasan sesuai dengan hukum;

c. Penangkapan, penahanan, atau tindak pidana penjara anak hanya dilakukan apabila sesuai dengan hukum yang berlaku dan hanya dapat dilakukan sebagai upaya terakhir.

Dan Pasal 17 Perda menyebutkan bahwa Setiap anak yang dirampas kebebasannya berhak untuk :

a. mendapatkan perlakuan secara manusiawi dan penempatannya dipisahkan dari orang dewasa;

b. memperoleh bantuan hukum atau bantuan lainnya secara efektif dalam setiap tahapan upaya hukum yang berlaku; dan

c. membela diri dan memperoleh keadilan di depan pengadilan anak yang objektif dan tidak memihak dalam sidang tertutup untuk umum.

d. Setiap anak yang menjadi korban atau pelaku kekerasan seksual atau yang berhadapan dengan hukum berhak dirahasiakan.

Melihat adanya kelemahan yang ditemukan dalam Peraturan lain diatasnya yakni Undang-undang Nomor 11 Tahun 2012 dan Peraturan Mahkamah Agung/PERMA Nomor 4 Tahun 2014 yang mengatur mengenai Diversi, Peraturan Daerah Kuningan Nomor 15 Tahun 2014 tidak melengkapi kelemahan yang masih dan belum diatur dalam peraturan diatasnya tersebut.

\section{SARAN}

Adapun saran yang dapat penulis berikan sehubungan dengan penulisan skripsi ini, sebagai berikut : Berkaitan dengan Peraturan Daerah mempunyai kedudukan yang strategis, karena diberikan landasan konstitusional yang jelas sebagaimana diatur dalam Pasal 18 ayat (6) Undang-undang Dasar Republik Indonesia Tahun 1945. Peraturan Daerah memiliki beberapa fungsi, seperti sebagai instrumen kebijakan untuk melaksanakan otonomi daerah dan tugas pembantuan sebagaimana amanat UndangUndang Dasar Negara Republik Indonesia Tahun 1945 dan Undang-Undang tentang Pemerintahan Daerah. Kemudian, fungsi yang kedua sebagai penampung kekhususan dan keragaman daerah, serta penyalur aspirasi masyarakat di daerah. Jadi segala hal yang masih kurang dalam hal pengaturan khusunya mengenai kebijakan diversi dalam Undang-Undang Nomor 11 Tahun 2012 dan Peraturan Mahkamah Agung/PERMA Nomor 4 Tahun 2014 dapat dilengkapi oleh Peraturan Daerah dan Kabupaeten Kuningan memang memiliki Peraturan Daerah Nomor 15 Tahun 2013 mengenai penyelenggaraan perlindungan anak, namun isinya masih umum mengatur perlindungan anak dan tidak melengkapi kelemahan pengaturan yang masih di temukan dalam Undang-undang Nomor 11 Tahun 2012 dan Peraturan Mahkamah Agung/PERMA Nomor 4 Tahun 2014 khususnya mengenai Diversi, sehingga perlu kiranya legislator di Kabupaten Kuningan untuk bisa merubah atau merevisi Peraturan Daerah tersebut sesuai kebutuhan yang berkaitan dengan kelemahan dari peraturan diatasnya dan isi dari setiap pasal harus bisa pula menggambarkan nilai dari kehidupan masyarakat Kuningan.

\section{DAFTAR PUSTAKA}

Jeremy Bentham, 2016, Teori Perundang undangan, Prinsip-Prinsip Legislasi, Hukum Perdata dan Hukum Pidana, Bandung: Penerbit Nuasa.

John Rawls, 1971, A theori. 
Munir Fuady, 2011, Teori Negara Hukum Modern (rechtstaat), Bandung: Refika Aditama.

Muttya Keteng, Andi. (2014, 30 Desember). Komnas PA Prediksi Pelaku Kekerasan Anak Meningkat 18\% Tahun 2015. Liputan 6 [Online], halaman 1. Tersedia: http://news.liputan6.com/read/2154228/ komnas-pa-prediksi-pelaku-kekerasananak-meningkat-18-tahun-2015 [ 21 Februari 2017], diakses tanggal 21 februari 2017 pukul 10.45.

Novie Amalia Nugraheni, Sistem Pemidanaan Edukatif Terhadap Anak Sebagai Pelaku Tindak Pidana, Skripsi FH Undip

Sekhroni. Criminal Liability dan Diversi Terhadap Tindak Pidana Anak dalam Sistem Peradilan Anak di Indonesia. Jurnal Unifikasi. ISSN 2354-5976 Vol. 03 Nomor 01 Januari 2016. Kuningan : FH UNIKU. DOI: https://doi.org/10.25134/unifikasi.v3i1.405

Soerjono Soekanto dan Sri Mamudji, 1985, Penelitian Hukum Normatif, Suatu Tinjaun Singkat, Jakarta: Rajawali.

Steven Allen, 2003, Analisa Situasi Peradilan Pidana Anak ( Juvenile Justice Sistem) di Indonesia. UNICEF, Indonesia.

Peraturan Perundang-undangan

Undang-Undang Dasar Negara Republik Indonesia 1945

Undang-Undang Nomor 39 Tahun 1999 tentang Hak Asasi Manusia.

Undang-Undang Nomor 11 Tahun 2012 tentang Sistem Peradilan Pidana Anak.

Undang-Undang Nomor 1 Tahun 2016 tentang Perlindungan Anak.

Peraturan Mahkamah Agung Nomor 4 Tahun 2014 tentang Pedoman Pelaksanaan Diversi Dalam Sistem Peradilan Pidana Anak. Peraturan Daerah Kabupaten Kuningan Nomor 15 Tahun 2013 tentang Penyelenggaraan Perlindungan Anak. 